\title{
A Novel, Bio-Reducible Gene Vector Containing Arginine and Histidine Enhances Gene Transfection and Expression of Plasmid DNA
}

\author{
Ko TanakA, ${ }^{a, \#}$ Takanori Kanazawa,,${ }^{a \#}$ Takaya Ogawa, ${ }^{a}$ Yumiko SudA,${ }^{a}$ Yuuki TaKashima, ${ }^{a}$ \\ Tsunehiko FuKudA, ${ }^{b}$ and Hiroaki OKADA $*, a$ \\ ${ }^{a}$ Laboratory of Pharmaceutics and Drug Delivery, Department of Pharmaceutical Science, School of Pharmacy, Tokyo \\ University of Pharmacy and Life Sciences; 1432-1 Horinouchi, Hachioji, Tokyo 192-0392, Japan: and ${ }^{b}$ Nagahama \\ Institute of Bio-Science and Technology; 1266 Tamura, Nagahama, Shiga 526-0829, Japan.
}

Received August 24, 2010; accepted November 18, 2010; published online November 24, 2010

We have engineered a novel, non-viral, multifunctional gene vector $\left(\mathrm{STR}-\mathrm{CH}_{2} \mathrm{R}_{4} \mathrm{H}_{2} \mathrm{C}\right)$ that contained stearoyl (STR) and a block peptide consisting of Cys (C), His (H), and Arg (R). STR-CH $\mathrm{H}_{4} \mathrm{H}_{2} \mathrm{C}$ can form a stable nano-complex with plasmid DNA (pDNA) based on electronic interactions and disulfide cross linkages. In this study, we evaluated the efficacy of STR-CH $\mathrm{R}_{4} \mathrm{H}_{2} \mathrm{C}$ as a gene vector. We first determined the optimal weight ratio for STR- $\mathrm{CH}_{2} \mathrm{R}_{4} \mathrm{H}_{2} \mathrm{C} / \mathrm{pDNA}$ complexes. The complexes with a weight ratio of 50 showed the highest transfection efficacy. We also examined the transfection efficacy of $S T R-\mathrm{CH}_{2} \mathrm{R}_{4} \mathrm{H}_{2} \mathrm{C} / \mathrm{pDNA}$ complexes with or without serum and compared STR-CH $\mathrm{CH}_{4} \mathrm{H}_{2} \mathrm{C} / \mathrm{pDNA}$ transfection efficacy with that of Lipofectamine. Even in the presence of serum, STR- $\mathrm{CH}_{2} \mathrm{R}_{4} \mathrm{H}_{2} \mathrm{C}$ showed higher transfection efficacy than did Lipofectamine. In addition, we determined the mechanism of transfection of the $\mathrm{STR}-\mathrm{CH}_{2} \mathrm{R}_{4} \mathrm{H}_{2} \mathrm{C}$ /pDNA complexes using various cellular uptake inhibitors and evaluated its endosomal escape ability using chloroquine. Macropinocytosis was main cellular uptake pathway of STR-CH $\mathrm{C}_{4} \mathrm{H}_{2} \mathrm{C} / \mathrm{pDNA}$ complexes. Our results suggested that $\mathrm{STR}-\mathrm{CH}_{2} \mathrm{R}_{4} \mathrm{H}_{2} \mathrm{C}$ is a promising gene delivery system.

Key words disulfide-cross linkage; peptide gene vector; endosomal escape

Gene therapy using nucleic acids, such as plasmid DNA (pDNA) and small interfering RNA (siRNA), is a potential therapeutic tool for many diseases, including cancer, infection, and other gene-related diseases. ${ }^{1-5)}$ To exert a therapeutic effect, genes and nucleic acids must be delivered across the plasma membrane and into the target cells. However, almost all nucleic acids cannot permeate cell membranes as naked molecules and are unstable in the presence of nucleases. To develop nucleic acids as therapeutics, we must engineer vectors that can form stable complexes with nucleic acids and efficiently delivery them across the plasma membrane and into the cytoplasm and/or the nucleus of the cell. Viral vectors, including retrovirus, adenovirus, and adeno-associated virus vectors, have been widely investigated as vehicles for gene delivery. ${ }^{6-8)}$ Viral vectors generally exhibit highly efficient gene expression, but they pose high risks, including insertional mutagenesis, high immunogenicitiy, and cytotoxicity. Safer approaches to gene delivery utilize nonviral vectors such as polycations and cationic lipids that can form stable nano-size complexes with therapeutic nucleic acids via electrostatic interactions. These lipid-based vectors are expected to have applications as gene carriers. ${ }^{9,10)}$ However, the transfection efficacy of non-viral vectors is usually poor because pDNA/vector complexes rarely reach the cell nucleus and the pDNA is rarely transcribed. ${ }^{11)}$ To improve transfection efficacy, an ideal gene vector must be multifunctional. Specifically, engineered vectors must be able to enter the target cells, escape from the endosome, inhibit degradation of exogenous DNA by nucleases, and release the therapeutic gene allowing it to enter the nucleus. Gene vectors must have multi-functional moieties, including cell-penetrating moieties, endosomal buffering moieties, and targeting moieties or intracellular trafficking signals.

The intracellular uptake of macromolecules, such as pro- teins and genes, can be enhanced by cell-penetrating peptides (CPPs), such as the human immunodeficiency virus-1 (HIV1) Tat peptide ${ }^{12)}$ and the Drosophila antennapedia homeoprotein. ${ }^{13)}$ The Tat peptide is rich in arginine residues; there are six arginine residues and two lysine residues in the 13amino-acid residue stretch, and arginine residues play a critical role in intracellular uptake of Tat and other peptides. ${ }^{14-16)}$ It has been reported that the interaction of arginine-rich peptides with membrane-associated proteoglycans results in activation of Rac, leading to F-actin reorganization and macropinocytosis. ${ }^{17)}$ Specifically, the guanidine group in arginine interacts with the carbonate, sulfate, and phosphate of the proteoglycans on the cellular surface and serves as intracellular delivery carriers of peptides, nucleotides, and even nanoparticles like liposomes and polymer micelles. ${ }^{18,19)}$

Vectors must have a positive charge to deliver condense pDNA into cells. However, excess positive charge is associated with tissue and cellular toxicity. ${ }^{20)}$ To develop a new carrier of siRNA with high uptake efficacy and low cytotoxicity, we synthesized a bio-reducible carrier, stearoyl (STR)$\mathrm{CH}_{2} \mathrm{R}_{4} \mathrm{H}_{2} \mathrm{C}$, that can form stable complexes with nucleic acids by positive charge and disulfide cross linkage in the non-reducing environment of the extracellular space and then release siRNA in the reducing environment inside the cell, which promotes cleavage of the disulfide cross linkages. In a previous study, we evaluated the efficacy of STR- $\mathrm{CH}_{2} \mathrm{R}_{4} \mathrm{H}_{2} \mathrm{C}$ as a siRNA carrier. STR- $\mathrm{CH}_{2} \mathrm{R}_{4} \mathrm{H}_{2} \mathrm{C} /$ siRNA complexes showed significantly higher uptake and silencing effects than non-cross-linked carrier complexes. Furthermore, STR$\mathrm{CH}_{2} \mathrm{R}_{4} \mathrm{H}_{2} \mathrm{C} /$ anti-vascular endothelial growth factor (VEGF) siRNA complexes exerted high anti-tumor effect in vivo. ${ }^{21)}$

Moreover, to mediate efficient gene expression, pDNA complexes must escape the endosomal pathway after intracellular uptake and before transfer into the nucleus. We in- 
Table 1. Sequence of Peptide Vectors

\begin{tabular}{cl}
\hline \hline Peptide & \multicolumn{1}{c}{ Sequence } \\
\hline $\mathrm{CH}_{2} \mathrm{R}_{4} \mathrm{H}_{2} \mathrm{C}$ & $\mathrm{H}_{2} \mathrm{~N}-\mathrm{Cys}-(\mathrm{His})_{2}-(\mathrm{Arg})_{4}-(\mathrm{His})_{2} \mathrm{Cys}-\mathrm{COOH}$ \\
$\mathrm{STR}-\mathrm{CH}_{2} \mathrm{R}_{4} \mathrm{H}_{2} \mathrm{C}$ & $\mathrm{CH}_{3}\left(\mathrm{CH}_{2}\right)_{16}-\mathrm{CONH}-\mathrm{Cys}-(\mathrm{His})_{2}-(\mathrm{Arg})_{4}-(\mathrm{His})_{2}-\mathrm{Cys}-\mathrm{COOH}$ \\
\hline
\end{tabular}

corporated histidine residues into the carrier because histidine reportedly has buffering capacity in the acidic environment of endosomes. This buffering acts as a proton sponge, allowing intact complexes to escape from the endosomes.

In this study, we engineered a bio-reducible and multifunctional gene vector, STR- $\mathrm{CH}_{2} \mathrm{R}_{4} \mathrm{H}_{2} \mathrm{C}$, that has cysteine residues on the both end of the carrier peptide. The cysteine residues in the vector can form disulfide cross linkages in the extracellular environment that are cleaved upon entry into the reductive intracellular environment. We evaluated the endosomal escape ability of STR- $\mathrm{CH}_{2} \mathrm{R}_{4} \mathrm{H}_{2} \mathrm{C} / \mathrm{pLuc}$ complexes using chloroquine and the cellular uptake pathway of the vector using various inhibitors of endocytosis. In addition, we confirmed that pLuc was released from STR- $\mathrm{CH}_{2} \mathrm{R}_{4} \mathrm{H}_{2} \mathrm{C} /$ pLuc complexes by agarose electrophoresis with glutathione (GSH).

\section{Experimental}

Materials The plasmid DNA (pCMV-Luc), comprising a subcloned luciferase cDNA fragment at the HindIII and BamHI sites of pcDNA3.1, was amplified in Escherichia coli (DH5a) and purified using an Endfree Plasmid Maxi kit (QIAGEN, U.S.A.), followed by ethanol precipitation and dilution in Tris/ethylenediaminetetraacetic acid (EDTA) buffer. Plasmid DNA concentration was measured based on UV absorption at $260 \mathrm{~nm}$. Chloroquine diphosphate salt, filipin, carbobenzoxy-D-phenyl-L-phenyl-glycine (Z-PhePhe-Gly), chlorpromazine, amiloride hydrochloride hydrate, and L-buthionine-sulfox-imine (BSO) were purchased from Sigma-Aldrich (St Louis, MO, U.S.A.)

Synthesis of Peptide Vector $\mathrm{CH}_{2} \mathrm{R}_{4} \mathrm{H}_{2} \mathrm{C}$ was synthesized as a pDNA vector using the $\mathrm{F}$-moc-solid-phase peptide synthesis method with an $\mathrm{AB}$ 433A peptide synthesizer (Applied Biosystems, Japan). The peptide sequence is shown in Table $1 . \mathrm{CH}_{2} \mathrm{R}_{4} \mathrm{H}_{2} \mathrm{C}$ was purified by reverse-phase HPLC before use. The molecular weight of $\mathrm{CH}_{2} \mathrm{R}_{4} \mathrm{H}_{2} \mathrm{C}$ was 1398.9 as determined using matrix-assisted laser desorption ionization time-of-flight mass spectrometry (MALDI-TOF-MS). Stearic acid was conjugated to the N-terminal of $\mathrm{CH}_{2} \mathrm{R}_{4} \mathrm{H}_{2} \mathrm{C}$ using the solid-phase peptide synthesis method.

SYBR Green Exclusion Assay $\mathrm{CH}_{2} \mathrm{R}_{4} \mathrm{H}_{2} \mathrm{C} / \mathrm{pLuc}(1 \mu \mathrm{g})$ or STR$\mathrm{CH}_{2} \mathrm{R}_{4} \mathrm{H}_{2} \mathrm{C} / \mathrm{pLuc}(1 \mu \mathrm{g})$ complexes were prepared by mixing different weight ratios ranging from $1 / 1$ to $50 / 1$ peptide/nucleic acid. The mixtures were incubated at $4{ }^{\circ} \mathrm{C}$ until the thiol groups in the complexes reached a plateau.

SYBR Green solution was added to the pLuc solution and this mixture was incubated for $30 \mathrm{~min}$. STR- $\mathrm{CH}_{2} \mathrm{R}_{4} \mathrm{H}_{2} \mathrm{C}$ solution was added to the SYBR Green/pLuc solution at weight ratios ranging from 10 to 50 . After $2 \mathrm{~h}$, the fluorescence of each sample was measured using a microplate reader at $521 \mathrm{~nm}$. The fluorescence of naked pLuc was used as the standard for " $100 \%$ decondensed."

Cellular Uptake Assay $\operatorname{COS} 7$ cells $\left(2 \times 10^{5}\right.$ cells $)$ were seeded onto 6 well culture plates. After a 24-h incubation in Dulbecco's modified Eagle's medium (DMEM) containing 10\% fetal bovine serum (FBS), the cells were washed with phosphate buffered saline (PBS) and $1.9 \mathrm{ml}$ of FBS (-) DMEM was added before transfection with naked pDNA or pDNA $(1 \mu \mathrm{g})$ with $\mathrm{CH}_{2} \mathrm{R}_{4} \mathrm{H}_{2} \mathrm{C}$ (w/w ratio; 50), or STR- $\mathrm{CH}_{2} \mathrm{R}_{4} \mathrm{H}_{2} \mathrm{C}$ (w/w ratio: 50) in $100 \mu \mathrm{l}$ of FBS (-) DMEM. After a 4-h incubation, the culture medium was aspirated and the cells were washed with PBS. After detachment by pipetting and resuspension in PBS, the cells were analyzed using flow cytometry (BD FACSCanto, Japan)

In Vitro Transfection COS7 cells were cultured to $70-80 \%$ confluence in (DMEM, Invitrogen Co., U.S.A.) containing 10\% FBS (Invitrogen) and $1 \%$ penicillin/streptomycin (stock $10000 \mathrm{U} / \mathrm{ml}, 10000 \mathrm{mg} / \mu 1$, Invitrogen).

COS7 cells $\left(5 \times 10^{5}\right.$ cells) were seeded onto 6-well culture plates. After 24 $\mathrm{h}$ incubation in DMEM containing $10 \%$ FBS, the cells were rinsed with PBS and then $1.9 \mathrm{ml}$ of culture medium (Opti-MEM) with or without FBS was added to each well. The pLuc complex solution $(100 \mu$ l containing $1 \mu \mathrm{g}$ of pLuc) was applied to each well. After $4 \mathrm{~h}$, the medium was removed and replaced by $10 \%$ FBS containing DMEM for further incubation. After $20 \mathrm{~h}$, the cells were washed three times with PBS, lysed by addition of $100 \mu 1$ of lysis buffer per well, and left to stand for $15 \mathrm{~min}$ at room temperature. Cell lysates were then collected and centrifuged at $15000 \mathrm{rpm}$ for $3 \mathrm{~min}$. After addition of $20 \mu \mathrm{l}$ of luciferase substrate solution to $40 \mu \mathrm{l}$ of cell lysate, the luciferase activity was measured using MicroLumat Plus LB96V, a chemiluminescence instrument (MicroLumat Plus LB96V; Berthold, Germany). The protein concentration of each cell lysate was determined using a standard BioRad protein assay kit (Bio-Rad, Hercules, CA, U.S.A.). Briefly, $5 \mu \mathrm{l}$ of cell lysate was diluted by a factor of 160 with ultrapure water and then incubated with $40 \mu \mathrm{l}$ of dye reagent for $1 \mathrm{~h}$ at room temperature; the absorbance was then measured at $595 \mathrm{~nm}$ using the microplate reader (Tecan Safire, Tecan Trading AG, Switzerland). The protein concentration of the cell lysate was calculated using a calibration curve generated with BSA standards $(2 \mathrm{mg} / \mathrm{ml})$. The results are shown as relative light units (RLU) per mg of protein.

In Vitro Cytotoxicity COS7 cells $(25000 \mathrm{cells} / \mathrm{well})$ in $100 \mu \mathrm{l}$ of DMEM containing 10\% FBS were seeded onto 96-well plates and incubated. After $24 \mathrm{~h}$, the COS7 cells were washed three times with PBS and transfected with pLuc complex solution (100 $\mu$ l containing $1 \mu \mathrm{g}$ of pLuc). After transfection/incubation for $4 \mathrm{~h}$, the cells were washed three times with PBS and cultured in DMEM containing 10\% FBS for $20 \mathrm{~h}$. CCK- 8 solution was added to each well, and the cells were incubated for $4 \mathrm{~h}$; the absorbance of the cells in each well was measured using the microplate reader at $450 \mathrm{~nm}$. The absorbance of control cells was set as the $100 \%$ viability standard, and the viability of all cells was expressed as a percentage relative to the absorbance of the control cells.

Transfection Mechanism Chloroquine was used to evaluate the endosomal escape ability of the vectors in COS7 cells. COS7 cells $\left(5 \times 10^{5}\right.$ cells $)$ were seeded onto 6-well culture plates. After $24 \mathrm{~h}$ incubation in DMEM containing $10 \% \mathrm{FBS}$, the cells were rinsed with PBS and then $1.9 \mathrm{ml}$ of culture medium (Opti- minimum essential medium (MEM)) with or without FBS was added to each well. Before transfection, the some cells were pre-treated with chloroquine $(100 \mu \mathrm{m})$ for $30 \mathrm{~min}$, pLuc complex solution $(100 \mu \mathrm{l}$ containing $1 \mu \mathrm{g}$ of pLuc) was applied to each well, and cells were then incubated in the presence or absence of chloroquine during transfection. After transfection for $4 \mathrm{~h}$, the medium was removed and replaced with DMEM containing $10 \% \mathrm{FBS}$, and the cell were incubated for $20 \mathrm{~h}$. Results were expressed as a percentage of light units (RLU) per mg of protein relative to control cells that were incubated under normal in vitro transfection conditions.

The mechanism of pLuc transfection via the STR- $\mathrm{CH}_{2} \mathrm{R}_{4} \mathrm{H}_{2} \mathrm{C}$ vector was determined in COS7 cells. The cells were incubated with pLuc complex solution ( $100 \mu \mathrm{l}$ containing $1 \mu \mathrm{g}$ of pLuc) at $37^{\circ} \mathrm{C}$ for $4 \mathrm{~h}$ after preincubation with the macropinocytosis inhibitor amiloride, the endocytosis inhibitors cholorpromazine and filipin, or the fusion inhibitor Z-Phe-Phe-Gly for $30 \mathrm{~min}$. The active uptake mechanism of pLuc was determined by incubation at $4{ }^{\circ} \mathrm{C}$ for $4 \mathrm{~h}$. Results were expressed as a percentage of light units (RLU) per $\mathrm{mg}$ of protein relative to control cells that were incubated under normal in vitro transfection conditions.

Intranuclear Amount of Cy5-Labeled pLuc The Cy5-labeled pLuc complexes were applied to the COS7 cells in a manner similar to the procedure for in vitro transfection. The culture medium was aspirated and cells were washed twice with PBS. To collect nuclei, $500 \mu$ l of lysis buffer ( $\mathrm{pH}$ 7.4, $10 \mathrm{~mm}$ tris(hydroxyl)aminomethane-HCl, $10 \mathrm{~mm} \mathrm{NaCl}, 3 \mathrm{~mm} \mathrm{MgCl}_{2}$, and $1 \%$ Nonidet P-40) was added to the cells. The cells were resuspended in PBS; the fluorescence intensity of Cy5-pLuc in the nuclei was analyzed using a microplate reader (Safire Microplate Reader, Tecan) after centrifuged at $3000 \mathrm{rpm}$ for $5 \mathrm{~min}$. The pLuc amount in the nuclei was calculated using a calibration curve generated with Cy5-labeled pLuc standards. The results show pLuc amount per nucleus.

In Vitro pLuc Release from Complexes with Vector To evaluate ability of form action of complexes with pLuc and the release of pLuc from the 


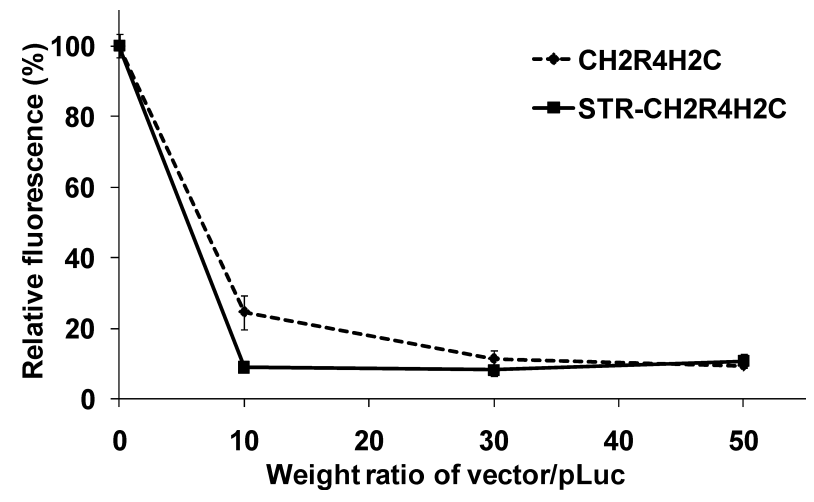

Fig. 1. SYBR Green Exclusion Assay of STR- $\mathrm{CH}_{2} \mathrm{R}_{4} \mathrm{H}_{2} \mathrm{C} / \mathrm{pLuc}$ Complexes

The STR- $\mathrm{CH}_{2} \mathrm{R}_{4} \mathrm{H}_{2} \mathrm{C} / \mathrm{pLuc}$ and $\mathrm{CH}_{2} \mathrm{R}_{4} \mathrm{H}_{2} \mathrm{C} / \mathrm{pLuc}$ complexes at several weight ratios were prepared at room temperature for $24 \mathrm{~h}$. Fluorescence was measured using a microplate reader. Each point represents the mean \pm S.D. $(n=3)$.

peptide vector complexes, agarose gel electrophoresis in tris-borate-EDTA buffer (TBE: $40 \mathrm{~nm}$ tris-borate, $1 \mathrm{~mm}$ EDTA, $\mathrm{pH}$ 7.4) with or without GSH and anions such as $\mathrm{NaCl}$ and heparin was carried out. STR- $\mathrm{CH}_{2} \mathrm{R}_{4} \mathrm{H}_{2} \mathrm{C} / \mathrm{pLuc}$ complexes were loaded onto a $1 \%$ agarose gel containing ethidium bromide $(0.5 \mathrm{mg} / \mathrm{ml})$ and electrophoresed in TBE buffer $(0.25 \%)$ at $100 \mathrm{~V}$ for $40 \mathrm{~min}$. The gel was visualized on a UV illuminator to assess the location of the pLuc DNA.

Statistical Analysis All data are expressed as the mean \pm S.D. Statistical analysis of the data was performed using an unpaired Student's $t$-test. Statistical significance was defined as $* p<0.05$ and $* * p<0.01$.

\section{Results and Discussion}

Characterization of pDNA Complexes We determined the condensation or complex formation of $\mathrm{pLuc}$ with $\mathrm{CH}_{2} \mathrm{R}_{4} \mathrm{H}_{2} \mathrm{C}$ and STR- $\mathrm{CH}_{2} \mathrm{R}_{4} \mathrm{H}_{2} \mathrm{C}$ using the SYBR Green exclusion assay. As shown in Fig. 1, the decrease in fluorescence intensity as STR- $\mathrm{CH}_{2} \mathrm{R}_{4} \mathrm{H}_{2} \mathrm{C} / \mathrm{pLuc}$ complexes formed depended on the weight ratio. Decreases in the fluorescence intensity reached a plateau at a weight ratio of 10 , suggesting that complex formation at a weight ratio of 10 was sufficient to condense all plasmid and that the condensation was driven by the positive charge on the arginine and disulfide cross linkages between cysteines in the peptide vectors. In contrast, $\mathrm{CH}_{2} \mathrm{R}_{4} \mathrm{H}_{2} \mathrm{C} / \mathrm{pLuc}$ complexes at a weight ratio of 10 was not sufficient to condense all plasmid, indicating that modification with STR enhanced condense ability by hydrophobic interaction between STR- $\mathrm{CH}_{2} \mathrm{R}_{4} \mathrm{H}_{2} \mathrm{C}$ and pLuc.

The particle size of the STR- $\mathrm{CH}_{2} \mathrm{R}_{4} \mathrm{H}_{2} \mathrm{C} / \mathrm{pLuc}$ complexes was about $100 \mathrm{~nm}$, and the zeta potential was about $20 \mathrm{mV}$. This zeta potential indicated that the basic amino acids, including Arg and His, in the STR- $\mathrm{CH}_{2} \mathrm{R}_{4} \mathrm{H}_{2} \mathrm{C}$ vector appeared on the surface of complexes, and these amino acids were expected to mediate high cellular uptake and gene expression.

Cellular Uptake We determined cellular uptake of Cy-5 labeled pDNA by COS7 cells using flow cytometry (Fig. 2). STR- $\mathrm{CH}_{2} \mathrm{R}_{4} \mathrm{H}_{2} \mathrm{C} / \mathrm{Cy} 5$-pDNA complexes showed significantly higher cellular uptake than $\mathrm{CH}_{2} \mathrm{R}_{4} \mathrm{H}_{2} \mathrm{C} / \mathrm{Cy} 5-\mathrm{pDNA}$ complexes, indicating that modification with stearic acid enhanced cellular uptake because of high membrane affinity of stearic acid. A previous study has already demonstrated the advantages of a hydrophobic moiety and conjugation of a cationic carrier. ${ }^{22)}$ Futaki et al. also reported that N-terminal stearylation of arginine rich peptides enhanced the cellular

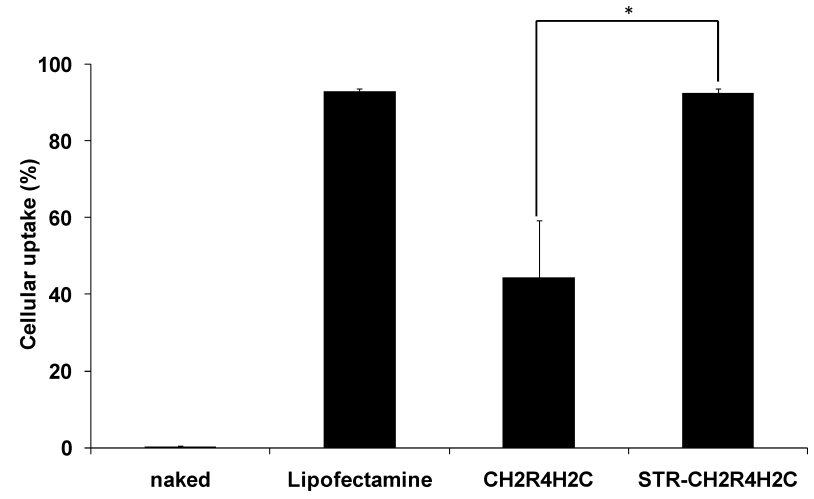

Fig. 2. Cellular Uptake Ability of STR- $\mathrm{CH}_{2} \mathrm{R}_{4} \mathrm{H}_{2} \mathrm{C} / \mathrm{pDNA}$ Complexes Cy5-pDNA $(1 \mu \mathrm{g})$ complexes with STR- $\mathrm{CH}_{2} \mathrm{R}_{4} \mathrm{H}_{2} \mathrm{C}$ (w/w ratio: 50), $\mathrm{CH}_{2} \mathrm{R}_{4} \mathrm{H}_{2} \mathrm{C}$ (w/w ratio: 50) was transfected into COS-7 cells with FBS(-) DMEM for $4 \mathrm{~h}$. Cellular uptake ability was determined by flow cytometry. Each bar represents the mean \pm S.D. $(n=3) . * p<0.02$.

uptake ability and the transfection efficacy because the hydrophobic moiety of the stearyl oligo arginine/DNA complexes could contribute to association between the complexes and the membranes. ${ }^{23)}$ In view of these reports, we thought our carrier, STR- $\mathrm{CH}_{2} \mathrm{R}_{4} \mathrm{H}_{2} \mathrm{C}$, would enhance not only the condensation and stability, but also the cellular uptake because of the stearic acid modification.

In Vitro Transfection The transfection experiments were performed using a luciferase reporter gene assay in COS7 cells. STR- $\mathrm{CH}_{2} \mathrm{R}_{4} \mathrm{H}_{2} \mathrm{C} / \mathrm{pLuc}$ complexes were prepared at weight ratios ranging from $10(\mathrm{~N} / \mathrm{P}$ ratio: 8$)$ to $50(\mathrm{~N} / \mathrm{P}$ ratio: 38) and compared with $\mathrm{CH}_{2} \mathrm{R}_{4} \mathrm{H}_{2} \mathrm{C} / \mathrm{pLuc}$ complexes at a weight ratio of 50 (N/P ratio: 45$)$.

Figure $3 \mathrm{a}$ shows the results of the transfection assays in COS7 cells in the absence of serum. The transfection efficacy with STR- $\mathrm{CH}_{2} \mathrm{R}_{4} \mathrm{H}_{2} \mathrm{C}$ increased with increasing weight ratios. The transfection efficacy of STR-CH $\mathrm{R}_{4} \mathrm{H}_{2} \mathrm{C}$ complexes at a weight ratio of 50 was higher than that of $\mathrm{CH}_{2} \mathrm{R}_{4} \mathrm{H}_{2} \mathrm{C}$. This observation suggested that the addition of stearic acid increased cellular uptake and fusion with the endosomal membrane because of the high membrane affinity of stearic acid. Figure $3 \mathrm{~b}$ shows luciferase activity of STR$\mathrm{CH}_{2} \mathrm{R}_{4} \mathrm{H}_{2} \mathrm{C} / \mathrm{pLuc}$ complexes transfected into COS7 cells in the absence and presence of serum. Even in the presence of serum, STR- $\mathrm{CH}_{2} \mathrm{R}_{4} \mathrm{H}_{2} \mathrm{C}$ showed higher transfection efficacy than did Lipofectamine. This observation suggested that STR- $\mathrm{CH}_{2} \mathrm{R}_{4} \mathrm{H}_{2} \mathrm{C}$ may have a potential for gene delivery in vivo as well as in vitro. In our previous study, STR$\mathrm{CH}_{2} \mathrm{R}_{4} \mathrm{H}_{2} \mathrm{C}$ /anti-VEGF siRNA showed strong anti-tumor effects in vivo. ${ }^{21)}$ These results indicate that $\mathrm{STR}-\mathrm{CH}_{2} \mathrm{R}_{4} \mathrm{H}_{2} \mathrm{C}$ had tolerance to serum and exerted high transfection efficacy in the presence of serum. However, the transfection efficacy of STR- $\mathrm{CH}_{2} \mathrm{R}_{4} \mathrm{H}_{2} \mathrm{C} / \mathrm{pLuc}$ complexes with serum showed higher decrease than Lipofectamine. These results suggested that higher amount of pLuc in the STR- $\mathrm{CH}_{2} \mathrm{R}_{4} \mathrm{H}_{2} \mathrm{C} / \mathrm{pLuc}$ complexes exposed surface of the complexes and interacted with serum compared with that of Lipofectamine. In the future, we must improve tolerance property of STR- $\mathrm{CH}_{2} \mathrm{R}_{4} \mathrm{H}_{2} \mathrm{C}$ complexes against serum.

Furthermore, Fig. 3c shows the result of cytotoxicity of these peptide vectors in COS7 cells. STR- $\mathrm{CH}_{2} \mathrm{R}_{4} \mathrm{H}_{2} \mathrm{C}$ did not show cytotoxicity, indicating that $\mathrm{STR}-\mathrm{CH}_{2} \mathrm{R}_{4} \mathrm{H}_{2} \mathrm{C}$ is a safe 
(a)

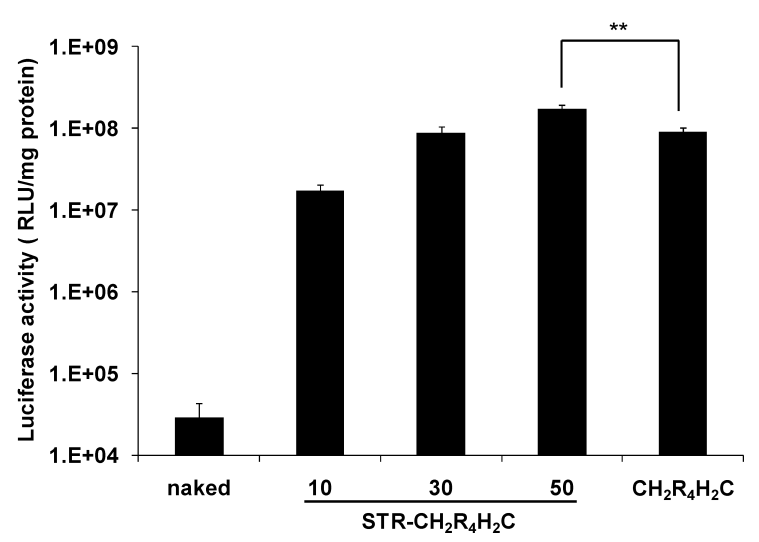

(b)

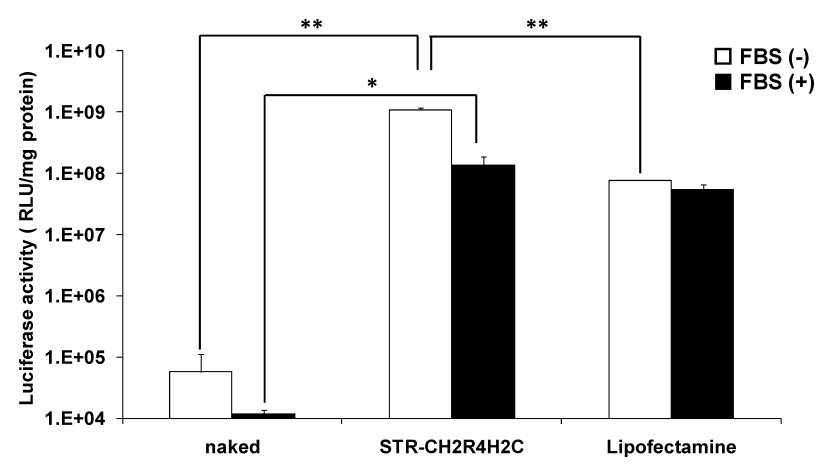

(c)

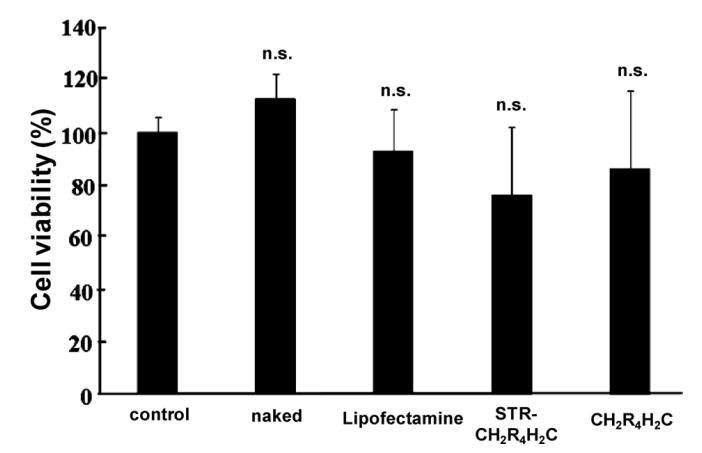

Fig. 3. In Vitro Transfection Efficacy and Cytotoxicity of STR-CH $\mathrm{R}_{4} \mathrm{H}_{2} \mathrm{C}$ (a) pLuc $(1 \mu \mathrm{g})$ complexes with $\mathrm{STR}-\mathrm{CH}_{2} \mathrm{R}_{4} \mathrm{H}_{2} \mathrm{C}$ (weight ratio: 10, 30, 50) or $\mathrm{CH}_{2} \mathrm{R}_{4} \mathrm{H}_{2} \mathrm{C}$ (weight ratio: 50) were transfected into COS7 cells without serum. After transfection for $24 \mathrm{~h}$, the luciferase activity in the COS7 cells was determined. Each bar represents the mean \pm S.D. $(n=3)$. $* * p<0.01$ (b) pLuc $(1 \mu \mathrm{g})$ complexes with STR $\mathrm{CH}_{2} \mathrm{R}_{4} \mathrm{H}_{2} \mathrm{C}$ (weight ratio: 50) were transfected into COS7 cells with serum. After transfection for $24 \mathrm{~h}$, luciferase activity in the COS7 cells was determined. Each bar represents the mean \pm S.D. $(n=3) . * p<0.05$, $* * p<0.01$ ( $t$-test). (c) pLuc $(1 \mu \mathrm{g})$ complexes with STR- $\mathrm{CH}_{2} \mathrm{R}_{4} \mathrm{H}_{2} \mathrm{C}$ (weight ratio: 50) or $\mathrm{CH}_{2} \mathrm{R}_{4} \mathrm{H}_{2} \mathrm{C}$ (weight ratio: 50) were transfected into COS7 cells without serum.WST- 8 assay was carried out $24 \mathrm{~h}$ after transfection. Each bar represents the mean \pm S.D. ( $n=3$ well). n.s., $p>0.05$ versus non-treated control ( $t$-test).

gene vector. However, the result of cytotoxicity of STR$\mathrm{CH}_{2} \mathrm{R}_{4} \mathrm{H}_{2} \mathrm{C}$ complexes showed wide viability, suggested that high weight ratio may cause these results. In the future, we must develop the carrier that exert high transfection efficacy at low weight ratio, which do not show cytotoxicity and wide viability.

Transfection Mechanism of STR- $\mathrm{CH}_{2} \mathbf{R}_{4} \mathrm{H}_{2} \mathrm{C}$ In order to examine the transfection mechanism of STR- $\mathrm{CH}_{2} \mathrm{R}_{4} \mathrm{H}_{2} \mathrm{C}$ complexes, the cells were incubated with chloroquine for $4 \mathrm{~h}$ before and during transfection. Chloroquine is a well-known endosome-disrupting agent that can promote endosomal escape and enhanced transfection efficacy. ${ }^{24)}$

As shown in Fig. 4a, transfection efficacies of $\mathrm{CH}_{2} \mathrm{R}_{4} \mathrm{H}_{2} \mathrm{C}$, STR-CHR ${ }_{4} \mathrm{HC}$ and STR- $\mathrm{CH}_{2} \mathrm{R}_{4} \mathrm{H}_{2} \mathrm{C}$ in the presence of chloroquine increased 7-fold, 5-fold and 2-fold, respectively, compared with transfection in the absence of chloroquine. Taken together, these results indicated that increasing the number of histidines, which exert a proton sponge effect, enhanced endosomal escape and modification with stearic acid increased fusion with endosomal membrane because of the high membrane affinity of stearic acid.

In order to confirm the cellular uptake pathway of STR$\mathrm{CH}_{2} \mathrm{R}_{4} \mathrm{H}_{2} \mathrm{C}$, the cells were incubated with various inhibitors for $4 \mathrm{~h}$ before transfection and during transfection. As shown in Fig. $4 b$, the transfection efficacy of STR- $\mathrm{CH}_{2} \mathrm{R}_{4} \mathrm{H}_{2} \mathrm{C}$ complexes decreased significantly in the presence of cholorpromazine and fusin, and especially in the presence of amiloride. Luciferase activity in the presence of these inhibitors was almost $0 \%$ of that in control cells that lacked inhibitor. These results suggested that macropinocytosis was the main cellular uptake pathway of the STR- $\mathrm{CH}_{2} \mathrm{R}_{4} \mathrm{H}_{2} \mathrm{C} /$ pLuc complexes. These observations were consistent with previous findings that suggest that macropinocytosis is induced by Arg residues, and they indicated that Arg residues were exposed on surface of the STR- $\mathrm{CH}_{2} \mathrm{R}_{4} \mathrm{H}_{2} \mathrm{C} / \mathrm{pLuc}$ complexes and enhanced cellular uptake. In previous report, Khalil et al. reported that main cellular uptake pathway of stearyl-octaarginine/pDNA complexes was the clathrin-mediated endocytosis, ${ }^{25)}$ which was different from our result. We think this difference was caused by density of arginine residue on the surface of the complexes. Kogure et al. reported that the cellular uptake of high density stearyl-occtaarginine modified liposome was strongly inhibited by amiloride (macropinocytosis inhibitor) ${ }^{26)}$ Our vector, STR$\mathrm{CH}_{2} \mathrm{R}_{4} \mathrm{H}_{2} \mathrm{C} / \mathrm{pDNA}$ complexes may have higher density of arginine on the surface of complexes than that of stearyl-octaarginine/pDNA complexes by disulfide cross-linkage of Cys residue in the complexes.

Figure $4 \mathrm{c}$ demonstrates the quantitative intranuclear uptake amount of Cy5-labeled pLuc in COS7 cells. Accumulation of the STR- $\mathrm{CH}_{2} \mathrm{R}_{4} \mathrm{H}_{2} \mathrm{C} / \mathrm{pLuc}$ complexes in the nuclei was significantly higher than that of Lipofectamine and $\mathrm{CH}_{2} \mathrm{R}_{4} \mathrm{H}_{2} \mathrm{C}$. Although, the cellular uptake amount of STR$\mathrm{CH}_{2} \mathrm{R}_{4} \mathrm{H}_{2} \mathrm{C} / \mathrm{pLuc}$ complexes in COS7 cells showed almost same level compared with that of Lipofectamine, STR$\mathrm{CH}_{2} \mathrm{R}_{4} \mathrm{H}_{2} \mathrm{C} / \mathrm{pLuc}$ complexes showed higher nuclear localization than Lipofectamine. These results suggested that cleavage of disulfide link in STR- $\mathrm{CH}_{2} \mathrm{R}_{4} \mathrm{H}_{2} \mathrm{C}$ complexes promoted the release of pLuc in the cytosol and that the released pLuc localize to the nucleus. As a result, STR- $\mathrm{CH}_{2} \mathrm{R}_{4} \mathrm{H}_{2} \mathrm{C} / \mathrm{pLuc}$ complexes showed high transfection efficacy in $\operatorname{COS} 7$ cells. These results indicated that the STR- $\mathrm{CH}_{2} \mathrm{R}_{4} \mathrm{H}_{2} \mathrm{C}$ vector exhibited multiple functions, including cellular uptake mainly via macropinocytosis, high endosomal escape, and efficient release of pLuc that led to nuclear localization. These functions mediated high transfection efficacy in COS7 cells.

In Vitro Release Figure 5a shows the transfection efficacy in COS7 cells in the presence of BSO, a glutamyl-Stransferase inhibitor. BSO inhibited cleavage of the disulfide cross linkages in the STR- $\mathrm{CH}_{2} \mathrm{R}_{4} \mathrm{H}_{2} \mathrm{C} / \mathrm{pLuc}$ complexes. Lipo- 
(a)

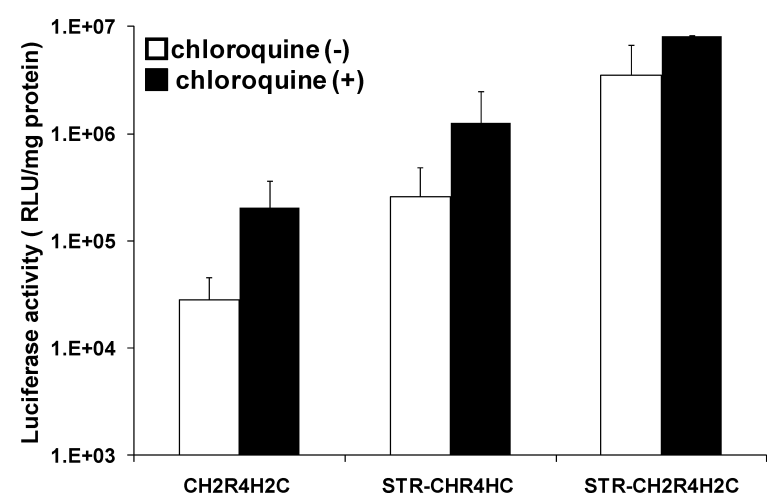

(b)

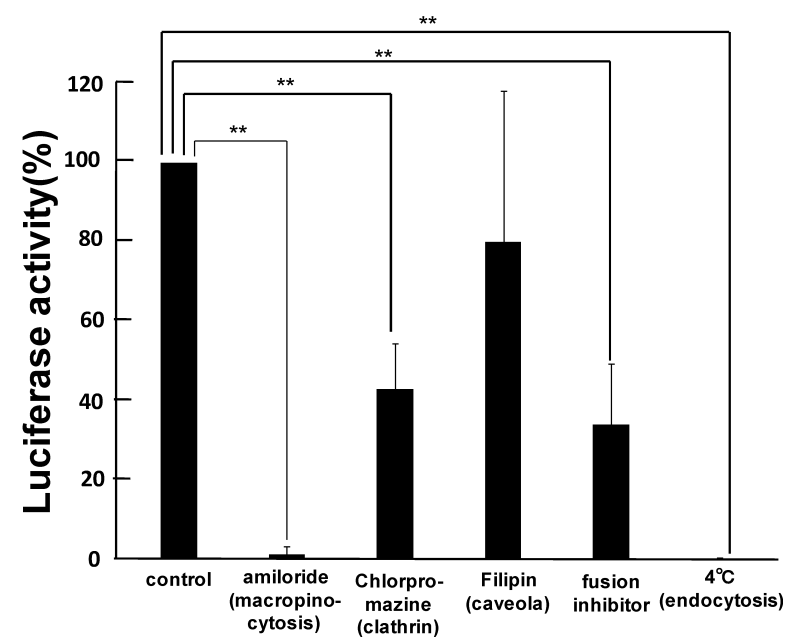

(c)

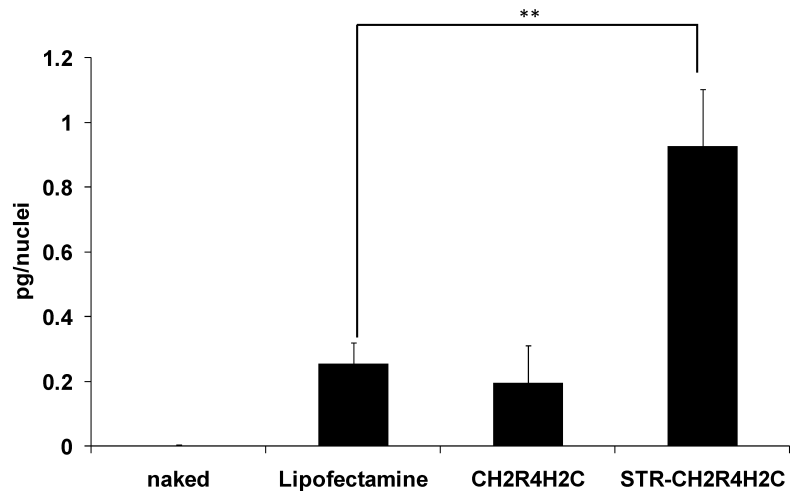

Fig. 4. Transfection Mechanism of STR- $\mathrm{CH}_{2} \mathrm{R}_{4} \mathrm{H}_{2} \mathrm{C} / \mathrm{pLuc}$ Complexes

(a) pLuc $(1 \mu \mathrm{g})$ complexes with STR- $\mathrm{CH}_{2} \mathrm{R}_{4} \mathrm{H}_{2} \mathrm{C}$ (weight ratio: 50), STR-CHR $4 \mathrm{HC}$ (weight ratio: 50) or $\mathrm{CH}_{2} \mathrm{R}_{4} \mathrm{H}_{2} \mathrm{C}$ (weight ratio: 50) were transfected in COS7 cells with or without chloroquine. After transfection for $24 \mathrm{~h}$, luciferase activity in the COS7 cells was determined. Each bar represents the mean \pm S.D. $(n=3)$. (b) COS7 cells were treated with amiloride $(3 \mathrm{~mm})$, chlorpromazine $(10 \mu \mathrm{g} / \mathrm{ml})$, filipin $(1 \mu \mathrm{g} / \mathrm{ml})$, fusion inhibitor $\left(100 \mu \mathrm{M} Z\right.$-Phe-Phe-Gly) or $4{ }^{\circ} \mathrm{C}$ transfection, respectively. Each bar represents the mean \pm S.D. $(n=3) . * * p<0.01$ ( $t$-test). (c) Cy5-labeled pLuc complexes were applied to the COS7 cells. After $24 \mathrm{~h}$ the fluorescence intensity of Cy5-pLuc in the nuclei was determined. The amount of pLuc in the nuclei was calculated using a calibration curve of a Cy5-labeled pLuc standard. Results show the amount of pLuc per nucleus. Each bar represents the mean \pm S.D. $(n=3)$. $* * p<0.01$ ( $t$-test $)$.

fectamine-mediated transfection resulted in nearly identical levels of luciferase activity in the presence and absence of BSO. In contrast, STR- $\mathrm{CH}_{2} \mathrm{R}_{4} \mathrm{H}_{2} \mathrm{C}$-mediated transfection was (a)

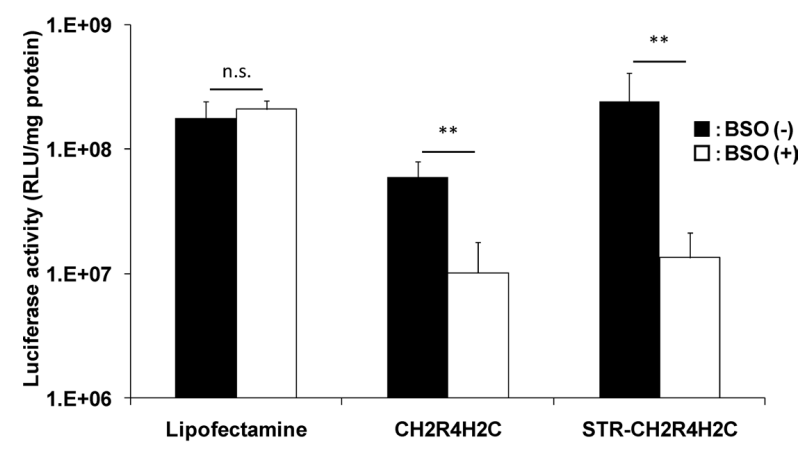

(b)

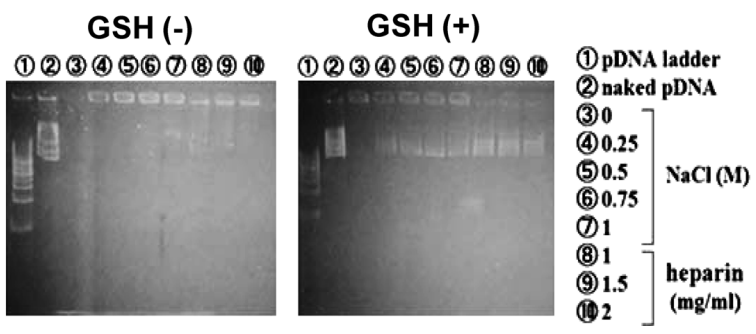

Fig. 5. In Vitro pLuc Release from STR-CH $\mathrm{R}_{4} \mathrm{H}_{2} \mathrm{C} / \mathrm{pLuc}$

(a) COS7 cells were treated with BSO (5 mM) $24 \mathrm{~h}$ before transfection. pLuc $(1 \mu \mathrm{g})$ complexes with STR- $\mathrm{CH}_{2} \mathrm{R}_{4} \mathrm{H}_{2} \mathrm{C}$ (weight ratio: 50), $\mathrm{CH}_{2} \mathrm{R}_{4} \mathrm{H}_{2} \mathrm{C}$ (weight ratio: 50) or Lipofectamine $(16 \mu \mathrm{g})$ were transfected into COS7 cells. After transfection for $24 \mathrm{~h}$, luciferase activity in the COS7 cells was determined. Each bar represents the mean \pm S.D. $(n=3)$. n.s., $* p<0.05, * * p<0.01$ ( $t$-test). (b) The complexes were prepared by mixing pLuc and STR- $\mathrm{CH}_{2} \mathrm{R}_{4} \mathrm{H}_{2} \mathrm{C}$ at room temperature for $2 \mathrm{~h}$. Complexes were further incubated with or without glutathione $(10 \mathrm{~mm})$ at $37^{\circ} \mathrm{C}$ for $2 \mathrm{~h}$. Before electrophoresis, the complexes were treated with $\mathrm{NaCl}(0.25-1 \mathrm{M})$ or heparine $(1-2 \mathrm{mg} / \mathrm{ml})$ and incubated at $37^{\circ} \mathrm{C}$ for $30 \mathrm{~min}$.

significantly lower in the presence of BSO than in the absence of BSO. This result suggested that high transfection efficacy of STR- $\mathrm{CH}_{2} \mathrm{R}_{4} \mathrm{H}_{2} \mathrm{C}$ could be attributed to the enhanced release of pLuc from the vector complex and that the release resulted from cleavage of the disulfide cross linkage.

The release of pLuc from complex at the weight ratio of 50 was evaluated by agarose gel electrophoresis (Fig. 5b). STR- $\mathrm{CH}_{2} \mathrm{R}_{4} \mathrm{H}_{2} \mathrm{C}$ can retard pLuc in the absence of $\mathrm{GSH}$, whereas pLuc was released from STR- $\mathrm{CH}_{2} \mathrm{R}_{4} \mathrm{H}_{2} \mathrm{C}$ in the presence of GSH. This result suggested that STR-CH $\mathrm{R}_{4} \mathrm{H}_{2} \mathrm{C}$ can release pLuc in the reducing environment inside the cell and that this bio-reducible vector has the potential to efficiently deliver genes to nuclei.

In conclusion, our results indicated that STR- $\mathrm{CH}_{2} \mathrm{R}_{4} \mathrm{H}_{2} \mathrm{C}$ enhanced transfection efficiency because of its proton sponge effect, tolerance to serum, and ability to release pDNA by cleavage of disulfide cross linkage in the intracellular environment. The findings reported in this study suggest that this novel peptide vector that contains Arg, His, and Cys is appropriate for clinical application and the delivery of therapeutic genes.

Acknowledgment We thank Mr. Ken Sugawara and Mr. Shogo Horiuchi (School of Pharmacy, Tokyo University of Pharmacy and Life Sciences) for his excellent technical assistance. This study was supported in part by a grant from the Promotion and Mutual Aid Corporation for Private Schools of Japan. 


\section{References}

1) Orlacchio A., Bernardi G., Orlacchio A., Martino S., Mini Rev. Med. Chem., 7, 1166-1176 (2007).

2) Pappas T. C., Bader A. G., Andruss B. F., Brown D., Ford L. P., Expert. Opin. Ther. Targets, 12, 115-127 (2008).

3) López-Fraga M., Wright N., Jiménez A., Infect. Disord. Drug Targets, 8, 262-273 (2008).

4) Dykxhoorn D. M., Expert. Opin. Ther. Pat., 19, 475-491 (2009).

5) Ponnappa, B. C., Curr. Opin. Investig. Drugs, 10, 418 - 424 (2009).

6) D’Costa J., Mansfield S. G., Humeau L. M., Curr. Opin. Mol. Ther, 11, 554-564 (2009)

7) Kesisoglou F., Schmiedlin-Ren P., Fleisher D., Zimmermann E. M., Mol. Pharm., 7, 619-629 (2010).

8) Björklund T., Carlsson T., Cederfjäll E. A., Carta M., Kirik D., Brain, 133, 496-511 (2010).

9) Ramsay E., Hadgraft J., Birchall J., Gumbleton M., Int. J. Pharm., 210, 97-107 (2000).

10) Ferrari M. E., Nguyen C. M., Zelphati O., Tsai Y., Felgner P. L., Hum. Gene Ther., 10, 341-351 (1998).

11) Kogure K., Akita H., Harashima H., J. Controlled Release, 122, 246251 (2007).

12) Nori A., Jensen K. D., Tijerina M., Kopecková P., Kopecek J., Bioconjug. Chem., 14, 44-50 (2003).

13) Lee J., Jung E., Park J., Park D., Biotechnol. Appl. Biochem., 42, 169 173 (2005).

14) Wender P. A., Mitchell D. J., Pattabiraman K., Pelkey E. T., Steinman L., Rothbard J. B., Proc. Natl. Acad. Sci. U.S.A., 97, 13003-13008
(2000).

15) Futaki S., Suzuki T., Ohashi W., Yagami T., Tanaka S., Ueda K., Sugiura Y., J. Biol. Chem., 276, 5836-5840 (2001).

16) Goun E. A., Pillow T. H., Jones L. R., Rothbard J. B., Wender P. A., Chembiochem., 7, 1497-1515 (2006).

17) Futaki S., Nakase I., Tadokoro A., Takeuchi T., Jones A. T., Biochem. Soc. Trans., 35, 784-787 (2007)

18) Khalil I. A., Kogure K., Futaki S., Harashima H., J. Biol. Chem., 281, 3544-3551 (2006).

19) Sethuraman V. A., Bae Y. H., J. Controlled Release, 118, 216-224 (2007).

20) Kleemann E., Jekel N., Dailey L. A., Roesler S., Fink L., Weissmann N., Schermuly R., Gessler T., Schmehl T., Roberts C. J., Seeger W., Kissel T., J. Drug Target, 17, 638-651 (2009).

21) Tanaka K., Kanazawa T., Ogawa T., Takashima Y., Fukuda T., Okada H., Int. J. Pharm., 398, 219-224 (2010).

22) Damen M., Aarbiou J., van Dongen S. F., Buijs-Offerman R. M., Spijkers P. P., van Zden Heuvel M., Kvashnina K., Nolte R. J., Scholte B. J., Feiters M. C., J. Controlled Release, 145, 33-39 (2010).

23) Futaki S., Ohashi W., Suzuki T., Niwa M., Tanaka S., Ueda K., Harashima H., Sugiura Y., Bioconjug. Chem., 12, 1005-1011 (2001).

24) Wolfert M. A., Seymour L. W., Gene Ther, 5, 409-411 (1998).

25) Khalil I. A., Futaki S., Niwa M., Baba Y., Kaji N., Kamiya H., Harashima H., Gene Ther, 11, 636-644 (2004).

26) Kogure K., Akita H., Yamada Y., Harashima H., Adv. Drug Deliv. Rev., 60, 559-571 (2008). 